Article

\title{
Universalism in Welfare Policy: The Swedish Case beyond 1990
}

\author{
Paula Blomqvist * and Joakim Palme \\ Department of Government, Uppsala University, 75120 Uppsala, Sweden; E-Mails: paula.blomqvist@statsvet.uu.se (P.B.), \\ joakim.palme@statsvet.uu.se (J.P.) \\ * Corresponding author
}

Submitted: 30 September 2019 | Accepted: 2 January 2020 | Published: 18 March 2020

\begin{abstract}
Despite its broad usage, universalism as a concept is not always clearly defined. In this article, a multidimensional definition of universalism in social policy is developed, based on four policy characteristics: inclusion, financing, provision, and the adequacy of benefits. In the empirical part of the article, the feasibility of this definition is tested by an analysis of recent changes in the Swedish welfare state, which is typically described as universal but has undergone substantive reforms since 1990. Four social policy areas are examined: pensions, social insurance, health care, and family policy. The results indicate that Swedish welfare policies retain their universalistic character in some dimensions but have become less universalistic in others. This demonstrates that a multidimensional approach is best suited to capture in full the nature and implications of welfare state reform.
\end{abstract}

\section{Keywords}

family policy; health care; pensions; social insurance; social protection; Sweden; universalist welfare; welfare state reform

Issue

This article is part of the issue "'Universalism' or 'Universalisms' in Social Policies?” edited by Monica Budowski (University of Fribourg, Switzerland) and Daniel Künzler (University of Fribourg, Switzerland).

(C) 2020 by the authors; licensee Cogitatio (Lisbon, Portugal). This article is licensed under a Creative Commons Attribution 4.0 International License (CC BY).

\section{Introduction}

Universalism has long been a central concept in social policy research, both as a goal and a characterization of policy instruments. It is typically used to describe social policies that include the whole population in a country, rather than just a targeted group, or which create separate programs for different groups. Universalism has been seen as a value both because it implies a higher level of social equity than selective or stratifying policies and because it has been shown to create a broader basis of popular support for public welfare programs. Controversies regarding universalism typically concern questions about distribution of benefits, and also the functioning and sustainability of welfare states (Beland, Marchildon, \& Prince, 2019; Kildal \& Kuhnle, 2005; Thompson \& Hoggett, 1996). Not infrequently, such discussions are confused by the ambiguity and fuzziness of the concept of universalism itself, which leaves it open to differing interpretations (Anttonen \& Sipilä,
2014). In addition, interpretations of universality have often differed between policy sectors. In this article it is argued that it is fruitful to formulate criteria for universal social policies that speak to both of the two main types of social benefits: cash-benefits and benefits inkind, i.e., social insurance and assimilated schemes, on the one hand, and social services, on the other hand. Drawing on previous research on the nature of universalism in social insurance as well as social services, a comprehensive definition of universalism is presented that combines four analytical dimensions: inclusion, financing, provision, and benefits. According to this definition, a fully universalist social program should (1) formally include all citizens on the same conditions, (2) be financed through public means only, (3) be managed by one actor only so that benefits are uniform, and (4) offer social benefits that are generous and of high quality, thereby making them relevant to all groups in society, including the better-off. While this definition is inspired by the Nordic experience with its extensive, publicly funded and admin- 
istrated welfare systems, universalism should be understood as an ideal type concept, rather than an empirical generalization. Using the construction of ideal type, that is, a pure ideal, makes it possible to describe and analyse the concept in more depth while at the same time acknowledging that full universalism is virtually impossible to obtain even if embraced as a policy goal.

The empirical part of the article treats the case of Sweden, which has often been pointed to as a prime example of a universalistic welfare state, but where reforms and retrenchment in the last decades have led to questioning whether this characteristic prevails (Berg, 2004; Clayton \& Pontusson, 1998; Lindbom, 2001). Drawing on a multidimensional definition of universalism, changes in the Swedish welfare state after 1990 are assessed in order to answer the question of whether, or to what extent, the system can still be described as universalistic. Four policy areas are examined: pensions, social insurance, family policy, and health care. The findings in the article show that the changes that have taken place have weakened the universalist character of the system, particularly with regard to the fashion in which the benefits are provided and the adequacy of the benefits. The analysis of the Swedish case demonstrates the usefulness of a comprehensive, multidimensional definition of universalism as this provides for more nuanced discussion of the effects of social reforms and their implications for social equity.

\section{The concept of Universalism}

Universalism has been broadly understood as the principle through which social protection and services are offered to all citizens as a matter of social right, rather than through means-testing or systems that are segmented by, for example, occupation or income levels (Esping-Andersen, 1990; Titmuss, 1976). This definition does not capture important differences between social programs with regard to their administration or adequacy in meeting social needs. When the principle of universalism was first promoted as a policy value in postwar Britain through the so-called Beveridge plan in the 1940s, universal social benefits were typically suggested to be uniform, or the same for all individuals (Baldwin, 1992). Later, most countries extended benefits in universal social programs to incorporate shifting needs and benefit levels as well as principles of income protection (Anttonen, Häikiö, \& Stefánsson, 2012, Chapter 1; Esping-Andersen, 1990). Furthermore, it appears that a more multi-dimensional interpretation of the concept is needed in order to understand the recent developments in many national welfare systems in the past decades, which have concerned not only formal rights to social benefits but also the manner in which they are provided (Albrekt Larsen \& Goul Andersen, 2015). In particular, reforms aimed at market-orienting systems of service provision have led to new forms of governance and a higher share of private service providers in sectors such as health, education, and social care (Bode, 2006; Gilbert, 2002; Kamerman \& Kahn, 2014). The new welfare mix of public and private elements that has developed as a result often challenges standard conceptions of what constitutes "public" or "universal" social programs and makes it hard to assess the implications for values such as social equity (Klenk \& Pavolini, 2015; le Grand \& Bartlett, 1993). A broader conceptualization of universality, which also includes characteristics such as service delivery and the administration of social programs, makes it possible to address the implications of such reforms as well. Another problem with most previous definitions of universalism is that they refer either to social protection systems (Korpi \& Palme, 1998), or to specific policy sectors in welfare services, such as health care or elder care (see, for instance, Carey, Crammond, \& de Leeuw, 2015; Szebehely \& Meagher, 2018). In the following, insights from prior research on universalism in both social insurance and social services are drawn upon in order to develop a fuller and more comprehensive definition of the concept.

With regard to social insurance programs, three fundamental questions can be posed in order to determine their character and degree of universalism (cf. Korpi \& Palme, 1998). First, are programs open to all or meanstested? Second, are programs segmented, with different insurance providers, or administered within the same (public) system for all? Third, are benefits paid at a flat rate or earnings-related? The third question may seem surprising, not least because many countries combine basic flat-rate and earnings-related provisions in, for instance, their pension system. Furthermore, as noted above, early definitions of universalism tended to describe benefits as flat rate, or uniform. Others have argued, however, that systems which only provide basic insurance benefits in practice invite private insurance to provide complementing income protection for the better-off, thereby undermining the universalist character of the system (Esping-Andersen, 1990; Korpi \& Palme, 1998). For this reason, it can be argued that it is important that social insurance systems have adequate earnings-related benefits in order to preserve universalism in the sense of the system being used by all income groups, not just those with relatively low incomes. This "adequacy logic," which was identified already by Titmuss (1955), is also applicable to the social services, where public services of poor quality, or which are too restricted in scope to cover the needs of the majority of the population, may pave the way for complementary private markets. From this it follows that a universal program is one that is not means-tested, is administered by the state as a unitary system rather than by separate organizations, includes benefit levels that are adequate enough and involve some degree of earningsrelatedness to prevent the development of complementary private markets for insurance against income loss.

In the case of social services, universalism has been discussed foremost in relation to financing (who pays) 
and access (who gets to use the services), but also the manner in which the services are provided and by whom. In contrast to benefits paid in cash, in-kind services tend to vary in terms of content and quality depending on how and by whom they are provided. This means that, while the discussion about income replacement versus flatrate benefits is less relevant in the service context, questions about the nature of the services and actors who deliver them are central. Distinctions in this regard are typically made between public, private for-profit, and private non-profit ownership. Another difference between cash benefits and social services is that the latter is often provided on the basis of assessed need for the particular service in kind, even if there is a general entitlement formulated in legal statutes. Here "need" then refers not to economic need, but need for the service in question, such as a specific medical treatment or care service.

It is usually argued that the most universalistic way of financing social services is general income taxation, as this implies that the financing is solidaristic (shared by all members in society on the basis of their financial ability), and that social risks, such as illness or injury, are pooled within the population as a whole, rather than smaller groups (Rothstein, 1998). Discussions about universalism in funding in the social services also include the size and construction of user fees, where such fees have been seen as a threat to universalism if they are so high that they prevent low income groups from using the services. On the other hand, reduced fees for such groups have not usually been seen as a breach with the universalist principle but rather as "targeting within universalism" (Skocpol, 1991).

When it comes to providing social services to users, it has been suggested that a fully universalistic form of provision exists when it is organized by public authorities to ensure that they have the same content for all (Anttonen, 2002; Anttonen et al., 2012). If service providers are private organizations or firms, particularly if subjected to competition, incentives for various forms of user selection, or picking the most "attractive" users, have often been highlighted as a problem. Private service providers, for example within primary education or health care, have also been known to discriminate among users in other ways, such as through specific "profiles", or through geographical location (Isaksson, Blomqvist, \& Winblad, 2016; le Grand \& Bartlett, 1993). Finally, previous research on universalism in the social services has also discussed patterns of service usage. Anttonen has argued that a social program can be regarded as universalistic only if it is not just open to but used by the great majority of the population when in need (Anttonen, 2002, p. 77). This implies that in order to be universalistic, a public social service program must be regarded as relevant by all groups in society, including those who can afford to purchase services on the market. This line of reasoning can be seen as a parallel to Korpi and Palme's argument about the need for universalistic social benefits to be perceived as "adequate" even by those with higher incomes. In the area of social services, questions regarding adequacy are often related to service quality and accessibility.

Combining insights on the nature of universalism in previous research on social insurance and welfare services, a general definition of universalism is proposed that comprises four dimensions:

- Inclusion, referring to who is formally included in social programs and whether they are open to all citizens on the same conditions;

- Financing, referring to whether social programs are financed by public or private means;

- Provision, referring to who is providing services or administering insurance systems and whether these actors are public, market-based, or voluntary/non-profit;

- Benefits, referring to whether social benefits are seen as adequate by all groups in society or if some groups choose to complement benefits with private solutions.

The multi-dimensional approach to universalism presented above suggests that universalism should not be understood as an "either/or" trait. Given the complexity of the concept, it seems apparent that a social program can be more or less universalistic or be universalistic with regard to some dimensions but not others. In this sense, one can talk of degrees of universalism. Perceiving universalism as constructed through different dimensions and constituting a scale rather than a dichotomy, or other categorical terms, also makes the concept more suited to assess changes in social programs over time.

\section{Universalism and the Swedish Model}

The contemporary Swedish welfare system is largely a post war construct, guided by principles of universalism and solidarity and with an overriding aim of promoting social equity. In the social protection programs, basic benefits were combined with earnings-related provisions and included families with children, the working aged, and the elderly. In the social services, programs were organized with the idea to support individuals from the cradle to the grave by entitlements to an increasingly broad range of welfare services, including health care, elder care, and childcare (Hort, 2014). During the 1980s the system came under increased pressure, both from structural changes in the economy, which brought unemployment and growing public deficits, and political criticism (Blomqvist \& Rothstein, 2000). The 1990s brought an economic crisis which exerted downward pressure on the social insurances and paved way for a series of reforms inspired by neoliberal ideas in the social services sector. While the appeal of "universal" social rights continues to be strong in Sweden, leading all major political parties to embrace this goal, at least rhetorically, there has been growing uncertainly and disagreement 
over what this concept actually entails. In the following, changes in four central welfare areas: pensions, sickness and unemployment insurance, health care, and family policy are reviewed in order to assess their effects with regard to universalism. Together, these areas make up a large part of the Swedish welfare state and include both social protection and social service programs.

\section{Pensions}

The universalistic trait of the Swedish pension system has a long tradition and dates back to the first reform in 1913 when Sweden became the first country in the world to introduce a pension system for the whole population, including women and non-workers (Edebalk, 1996). In practice, the system was not fully universal since the main expenditures were on the so-called means-tested supplements. It was not until the 1946-1948 reform that means-testing was completely abolished and a system of universal flat-rate pensions, where the entire benefits were paid without means-testing, was established. In 1959 , the public pension system was extended to include an earnings-related supplement. This two-tier system gradually expanded over the following decades and in principle came to incorporate the entire working population and provide relatively generous benefit levels, which in effect virtually eliminated private pension savings.

In 1998 a radical reform of the public pension system was introduced, shifting it from a so-called "defined benefit" formula to a "defined contributions" system, where the value of the benefits became linked to the performance of the economy, wage developments, and the longevity of the population (Palme, 2003). The intention behind the reform was to make the system more financially sustainable and to create stronger work incentives. The new Swedish pension system represented a policy shift in the direction of privatization and free choice, as it introduced more room for choice of pension funds, even on the private market, on the part of individual beneficiaries (Hinrichs, 2004). At the same time, the basic values of the previous system, e.g., to combine basic economic security with income protection for all retired citizens within the framework of a mandatory, publiclycontrolled system, were preserved. The reformed system is different in the sense that the income-related system has become the first tier and the basic benefit is now a guaranteed level rather than a common component of the benefit package of the retirees. The reform did not reduce access to the system, which is still paid by compulsory contributions and taxes. This implies that the post1998 system remains highly universalistic with regard to inclusion and financing. In fact, the basic, flat-rate level of pension benefits guaranteed in the 1998 system is slightly higher than in the old system. Moreover, benefits are still paid out by the state even if the size of the benefits may be affected by a slight privatization of risk through the individual choice of premium fund. At the same time, the new system is less predictable to benefi- ciaries and also calculated to be less generous in terms of replacement rates compared to the previous system. In this sense, the universality in the adequacy of benefits has been reduced.

The fact that benefits are more uncertain and less generous, especially for higher income groups, appears to have led to an increase in private pension savings in Sweden. In the early 2000 s, $35 \%$ of the working age population had private pension savings, compared with $17 \%$ in 1990 (Palmer, 2002; Palme, 2003). This can be said to represent a slight reduction in the universalistic character of the system's financing in so far as the public pension system has become complemented to a higher degree with market solutions. Given that the new system is more mixed in its provision structure and benefits are more dependent on individual choice of fund (and also retirement age), there is a weakening of universalism, also in the dimension of provision.

\section{Social Insurance: Sickness Leave and Unemployment Benefits}

The history of the major social insurance programs for the working population in Sweden is different from that of the pension system. Both sickness leave and unemployment benefits were organized in the form of a voluntary state-subsidized insurance in the first part of the 20th century. The increased public involvement in the system started with state subsidies being paid to sickness insurance funds in 1910, but it was not until 1934 that public subsidies of the unemployment insurance funds were legislated. Whereas sickness insurance was made both universal and compulsory in 1955, the unemployment insurance system has maintained its voluntary, state-subsidized character, even if a flat-rate benefit for uninsured persons was introduced in 1974. Benefits are earnings-related and standardized in both programs, with a cap for high-income earners. The unemployment insurance funds have remained administered by trade unions in line with the so-called Ghent model.

In 2010, a Centre-Right coalition government appointed a parliamentary social insurance commission to come up with reform proposals for the sickness and unemployment benefits, but no major changes were proposed in the end. This is typical of the developments in these programs over the last decades, as they have been characterized by small, ad hoc, adjustments and austerity measures rather than big reforms. Some of these "minor" changes have, however, had surprisingly large effects. One example is the increase in insured person's contributions for unemployment insurance, introduced in 2007, which led to a drastic drop in coverage. Additionally, "non-decisions" have contributed to a kind of drift (cf. Streeck \& Thelen, 2005) of the system: In 2012, a report revealed that there had in fact been a significant reduction in replacement levels over the last decades in both sickness and unemployment insurance. While the Swedish insurance programs used to 
be among the most generous in the OECD with regard to both replacement levels and benefit duration, by 2010 the Swedish programs scored average (Palme, Ferrarini, Sjöberg, \& Nelson, 2012).

Other changes that have been important for the development of the system in recent years include the introduction of earned income tax credits, which effectively reduced the net replacement rates of social insurance benefits. The benefit duration has also been subject to several restrictions, leading to a less generous system, particularly for those with long-term illness. In the case of the unemployment insurance, the government chose in 2007 to increase individual contributions to the earnings-related part of the system, a choice motivated by the belief that this would penalise excessive wage demands from the unions. The result was a dramatic decline not only in the coverage of the unemployment insurance but also in union density, from $80 \%$ to below $70 \%$. However, the individual contributions have gradually been reduced again since 2014 , restoring the previous level of universality in its financing structure.

In sum, sickness and unemployment insurance continue to differ as the latter is primarily administered by trade unions, which makes it more pluralistic and less universal in terms of provision. The financing of the unemployment insurance was at least for a period shifted in a less universal direction as the wage earners" contributions increased. The sickness insurance has retained its level of universalism both in terms of inclusion and administration. Concerning the adequacy of benefits, there has been some tightening of qualifying conditions for entitlements in both programs, not least when it comes to the duration of benefits. While benefits are still earnings-related in both cases, the income ceilings have declined significantly. This has led to a tendency towards privatization of sickness insurance, as there has been an increased reliance on collectively bargained, or trade union-provided benefits. While the collectively bargained programs cover $90 \%$ of employees in Sweden, they are particularly important for the higher income groups who are increasingly dependent on these programs to be adequately insured. This implies that the sickness insurance has become less universal both with regards to financing, provision and benefit adequacy (cf. Grees, 2015).

\section{Family Policy}

Swedish family policy has three main parts: cash benefits, parental insurance, and publicly financed childcare provision. Together, this creates what has been described as an earner-carer family model, where all individuals, regardless of gender, can be both income earners and child carers (Morgan, 2012). This policy orientation was strengthened during the 1990s and 2000s as both parental leave and access to childcare services were extended, and several new policy measures introduced to support fathers in their role as carers (Earles, 2011).
The Swedish child cash benefit program entitles all parents to a flat-rate allowance per child until the child turns 16. This is a universal program which includes all parents, regardless of income. The program was first introduced as a payment to all mothers in 1931 and has remained more or less intact since. In 2019, the size of the benefit was about 120 EUR per month. Paid parental leave was introduced in Sweden in 1974, entitling parents to 26 weeks of paid leave at a wage replacement of $90 \%$. It was gradually extended to 15 months in the early 1990s, with $90 \%$ wage replacement for the first 12 months, followed by three months with lower flat-rate compensation (according to Eurostat calculations, where paid parental leave corresponds to two-thirds of income replacement, the Swedish parental leave is 18.5 months). Following the economic recession in the mid-1990s, the wage replacement level was lowered to $80 \%$. In the early 2000s, the parental insurance was further extended in that one month of income-replacement was added to it, and at the same time the flat-rate benefits were increased The changes introduced in the parental leave scheme after 1990 have had the effect of making the system more generous, particularly with regard to the time period covered. At the same time, the fact that the ceiling set for income levels for benefit purposes, over which no replacement is provided, has remained more or less fixed while wage levels have increased implies that a higher share of the population will get significantly lower replacement levels than $80 \%$ : in this sense, benefit levels have become markedly less adequate.

The public childcare system has been characterized by a gradual expansion after 1990. At the beginning of the decade, $40 \%$ of all children aged 16 attended a publicly financed day care service. In 1995, access to childcare became a formal right for all children from the age of 1 , forcing local governments to increase the supply of services. Further steps to universalize the system were taken in 2001, when the right to (part-time) care was extended to the children of the unemployed, and in 2002, when the same right was extended to children of parents who were on parental leave with a sibling. In the same year, the government reduced user fees by introducing a maximum fee (maxtaxa) and making 525 hours of attendance free of charge for 4- and 5-year-olds (Hiilamo, 2004). In 2017, 84\% of all children aged 2 to 5 attended a care institution within the public childcare system (Swedish National Agency of Education, 2018). Quality in the system is generally regarded as high and has been rising further in recent decades due to prolonged university-level education for preschool teachers and the introduction of a national pedagogical curriculum (Sheridan, Williams, Sandberg, \& Vurinen, 2011). A significant development in the system in the early 1990s was the introduction of the right of the municipalities to delegate the task of providing childcare services to private organizations in exchange for public funding. Under this system of parental choice, private providers of childcare are subjected to the same regulation and na- 
tional curriculum as public providers and are financed on the same conditions with the same user fees. Since then, the share of private care providers within the system has grown steadily to about $25 \%$ in 2018 . It has been shown that highly educated parents are more inclined to opt for non-public providers but that there are no significant quality differences between these and public providers in terms of staffing levels and staff continuity, and that the educational level of the staff is in fact higher in the public sector than the private (Hanspers \& Mörk, 2011; Swedish National Agency of Education, 2018). The partial privatization of the provision of childcare services in Sweden has also led to services becoming more diverse in terms of pedagogical orientation.

With regard to the question of universalism, developments in Swedish family policies have been slightly contradictory after 1990. Along some dimensions of the concept, such as inclusion and financing, their universalist character has been strengthened. Both the parental insurance and the childcare system were extended during this period in ways that made them more, rather than less, inclusive. In childcare services, public subsidies have been markedly increased, while in the parental insurance, replacement levels were slightly reduced. At the same time, the benefit period was extended in parental insurance and the availability of childcare improved markedly. This points to benefit adequacy in the parental insurance system being reduced in some ways (replacement levels in the parental insurance) while improved in others (length of parental leave and more care services offered at a lower cost to parents). As for provision, there was a clear departure from the previous uniform, public model in that the share of private care providers increased significantly. The partial privatization of childcare provision during the period also led to services becoming more differentiated in their orientation, with many preschools today having distinct pedagogical profiles. General quality assessments, together with parent surveys, indicate, however, that the quality of the care is still high and that parents are generally very satisfied with the service (OECD, 2006; Swedish National Agency of Education 2018). The new mixed delivery system in childcare services in Sweden has thus led to a decrease in universality in the provision dimension. Benefit adequacy in this sector still appears high, however, in that the quality of the services are perceived as good by the vast majority of parents and there is no indication of the better-off turning to privately funded market alternatives.

\section{Health Care}

The Swedish health care system is an NHS-type system financed by income tax that provides entitlement to high quality care services for all citizens, regardless of income or employment. The system that developed in the postwar era had a high level of universalism in that services were largely standardized and provided almost exclu- sively by public hospitals and primary care centres at the local, or county, level. In the late 1980s, the share of private providers was estimated to be only a few percent, making it, in some estimations, the most publicly dominated system in the world (Blomqvist \& Winblad, 2013; Immergut, 1992).

Like other parts of the welfare services, the health care system became subject to increased political criticism during the 1980 s, leading to a series of reforms during the 1990s and 2000s, foremost in relation to the provision of health services. Argued by right-wing critics in particular to be characterized by low efficiency, inflexibility, and lack of sensitivity to patient demands, the system was gradually opened up to competition from private care providers, albeit within the framework of continued public funding and administration (Blomqvist, 2004; Blomqvist \& Winblad, 2013). During the 2010s, the policy orientation towards privatization of provision continued, particularly in the primary care sector after the socalled Primary Care Choice Reform in 2009. In this sector over $40 \%$ of all patient visits were made to private care providers in 2018 (Blomqvist \& Winblad, in press). However, since there has been less interest from the regional health authorities to advance privatization of provision in the hospital sector (such as through outsourcing or selling hospitals), the total share of private provision within the system has remained relatively low. In 2018, only six out of the country's 70 hospitals were privately owned (OECD \& European Observatory on Health Systems and Policies, 2019). Due to the single-payer organization of the system and the direct local political control over budgets, it has been known to have a high level of cost-control (Anell, Glenngård, \& Merkur, 2012). In 2018 the spending level was about $11 \%$ of GDP, which was higher than during the 1990s, when spending levels were reduced as a result of the financial crisis. The reduction in spending during this period was managed largely through rationalizations like closing and merging of hospitals and reducing staff, but also technological developments leading to increased productivity and shorter treatment periods (Blomqvist \& Winblad, in press). Other health policy changes during the period have been a strengthening of central regulatory control within the system through national clinical guidelines, quality registers, and the formalization of patient's rights with regard to waiting times, information, and co-determination through the 2015 Patient Rights Law. In 2005, a waitingtime guarantee was introduced which entitled all patients to specialist care treatment within a certain time limit (90 days).

Regarding the effects on the universalism of the health care system by the reforms undertaken since 1990, it can be noted, first, that there appears to be little change in relation to the dimension of inclusion. Inclusion can even be said to have been extended by a legal change in 2013 making the right to health care services that should be given "without delay" applicable not only to asylum seekers but to irregular migrants 
who stay in the county illegally. The guiding principle that all health services within the system should be distributed solely on the basis of medical need, rather than income or occupation, is still supported by all major political parties. Some have argued that the increase of private care givers within the primary care system threatens the needs principle, as it leads to an uneven geographic establishment of providers. Evaluations indicate that new private providers have located disproportionally in urban and more affluent areas (Isaksson et al., 2016) but also that there has been a general improvement in access for all groups as a result of their expansion within the system. In 2015, 99\% of the population could reach a primary care giver within 20 minutes, indicating a slight improvement compared to previous years. When it comes to the second universality dimension, financing, the Swedish health care system still has a very high share of public financing in comparison with other health care systems within the OECD, but there is a marginal trend of growth in private health insurance, foremost obtained through employment. In 2017, about 650,000 Swedes had voluntary health insurance, which represented a significant increase in only the recent decade, but still amounted to only about $6 \%$ of the population (Kullberg, Blomqvist, \& Winblad, 2019). In the third universality dimension, provision, there has been a marked change given the introduction of mixed provision. Even though there is some indication of stratification in that highincome groups are more likely to have chosen privately practicing GPs, there is no evidence of services provided by private care providers being of higher quality than public (or the other way around). Rather, most estimates of medical quality in the system point to a general improvement over the last decades, placing Sweden in the top of most international rankings of health system quality (Swedish Association of Local Authorities and Regions, 2015). Nonetheless, the growth in voluntary health insurance uptake and gradual development of complementary private health care markets during the period indicate a growing gap between what citizens and employers demand and what the public system can deliver. Several studies indicate that waiting times for specialist care in the public system, in particular, have been a contributing factor behind the growth in voluntary health insurance markets (Kullberg et al., 2019; Palme, 2017). This points to mixed evidence with regard to how the adequacy of benefits has developed in the health care system over the period; while there appears to have been an improvement in terms of medical quality, there has been a weakening in terms of access to care.

\section{Conclusion}

When summarizing the developments in the four welfare policy areas from the perspective of universalism, a complex and partly contradictory pattern emerges. Drawing on the multi-dimensional conceptualization developed in the beginning of the article, it can be observed that, in terms of inclusion, social programs remain by and large universalistic. If anything, they have become more inclusive, as in the cases of child- and health care. In the second dimension, financing, changes have been relatively small and public financing systems have generally prevailed, or, as in the case of childcare, been extended. In the third universalism dimension, provision, there has been more substantive change due to a policy trend towards privatization of provision in welfare services and a higher reliance on private, occupational insurance programs in sickness insurance. The privatization trend has led to social services becoming more diverse and consumption patterns more segregated, but with no apparent undermining of social equity through increased quality differences between public and private sectors. In the fourth dimension, the adequacy of benefits, developments are somewhat ambiguous. In the area of social insurance as well as in the parental leave program, it appears quite clear that benefits have become less adequate as income replacement rates have declined. In childcare services, benefits appear to have improved due to increased access and quality improvements. In health care, there are also clear indications of quality developments, particularly in terms of medical quality, but the adequacy of benefits has been reduced through the persistent problem of waiting times. Taken together, these findings indicate that, in three out of four dimensions, there have been at least slight reductions in the universalism of Swedish social policies over the past decades. The findings are summarized in Table 1.

How important these developments are for an overall assessment of the universalism of the Swedish welfare state depends on how the relative importance of the four dimensions is valued and to what extent they can be seen as interdependent. It can be argued that inclusion and financing are the most important, or basic, dimensions for the preservation of universality within a welfare system. Without formal inclusion of all citizens and public financing, there is no guaranteed access to social benefits for all, even at a minimum level. The adequacy dimension is also important, both directly and indirectly. If social benefits are not adequate, or able to address the needs of people, the value of being included in a welfare program and have it payed for by public means. becomes diluted. As noted, the lack of adequate benefits may also have an indirect effect by leading to an expansion of private markets for social protection and services. Such developments do not only undermine social equality but might lead to an erosion of political support for public welfare programs among those groups who turn to the market, most likely the upper and middle classes. If this happens, the financing of the system will be threatened as well. A weakening of the provision dimension is perhaps the most difficult to judge the consequences of, but the effects are likely to be most notable in the social services, where users interact with each other and the service providers. If systems for service delivery become more diverse, this could lead to growing differences in 
Table 1. Changes in dimensions of universalism in Swedish welfare 1990-2019.

\begin{tabular}{lllll}
\hline & Inclusion & Financing & Provision & Benefits \\
\hline Social insurance & constant & slightly reduced & reduced & reduced \\
Pensions & constant & slightly reduced & reduced & reduced \\
Family policy & extended (childcare) & extended & reduced & extended (childcare), mixed (parental insurance) \\
Health care & extended & constant & reduced & mixed \\
\hline
\end{tabular}

the status and quality of the services, which risks making systems more socially stratified. If quality differences increase, this might also affect the adequacy dimension of universalism, leading dissatisfied users to seek out market alternatives. Whether such a development occurs is likely to depend, however, in large measure on the public regulation of the services in question for example with regard to quality standards or conditions for access.

The findings in the article also indicate that, if there is a threat to the universality of the Swedish welfare system, it comes mainly from the tendency towards growing markets for social benefits outside the public programs. Developments in the future with regard to such complementary markets appear to depend not least on the adequacy of benefits offered through public social programs. At the same time, there are a number of factors that suggest that it might be possible to sustain the still relatively high over-all level of universalism in the Swedish welfare system. The first one is the public popularity of the universalist principle. As is well documented, populations in welfare states with a high level of universality in, for instance, inclusion and financing, support their welfare systems more strongly than populations in more selective or stratifying welfare states (Brady \& Bostic, 2015). This extends to individual programs in that universal programs tend to be more popular than means-tested ones (Rothstein, 1998). The fact that universal social policies tend to generate popular support is evident not least in the Swedish case, where there has long been a high level of public commitment to universally inclusive and publicly financed welfare programs (Svallfors, 2016). The second factor is that publicly controlled systems tend to be more effective in terms of cost control than systems with plural financers and administrators, a fact that is evident both in health care and pensions (Hsiao, 2007; Palme, 2005). Finally, it is also apparent that universalism in inclusion and financing, at least, are policy values which still have broad political support in Sweden, even among groups to the right on the political spectrum (Lindbom, 2016). On a more general level, the findings in the article suggest that when discussing the fate of universalism in mature welfare states, scholars should be careful to define the concept and use its different dimensions to trace and assess changes in social programs over time.

\section{Acknowledgments}

We wish to thank the participants at the research seminar at our department, in particular Nadja Grees, Pernilla
Tunberger and Johanna Söderström, Anders Lindbom and Christian Albrekt Larsen, as well as two anonymous reviewers and the editors for useful suggestions.

\section{Conflict of Interests}

The authors declare no conflict of interests.

\section{References}

Albrekt Larsen, C., \& Goul Andersen, J. (2015). Den universelle velfærdsstat [The Universal welfare state]. Copenhagen: Frydelund Academic.

Anell, A., Glenngård, A., \& Merkur, S. M. (2012). Sweden: Health systems review. Health systems in transition, 14(5), 1-159.

Anttonen, A. (2002). Universalism and social policy: A Nordic-feminist revaluation. Nordic Journal of Women's Studies, 10(2). https://doi.org/10.1080/ 080387402760262168

Anttonen, A., Häikiö, L., \& Stefánsson, K. (Eds.). (2012). Welfare state, universalism and diversity. Cheltenham: Edward Elgar.

Anttonen, A., \& Sipilä, J. (2014). Varieties of universalism (Draft paper prepared for the UNRISD Conference "New Directions in Social Policy: Alternatives from and to the Global South"). Retrieved from shorturl.at/ahDS5

Baldwin, P. (1992). Beveridge in the lounge durée. International Social Security Review, 45(1/2), 53-72.

Beland, D., Marchildon, G. P., \& Prince, J. (Eds.). (2019). Universality and social policy in Canada. Toronto: University of Toronto Press.

Berg, A. (2004). The universal welfare state: Theory and the case of Sweden. Political Studies, 52(4), 745-766.

Blomqvist, P. (2004). The choice revolution: Privatization of Swedish social services in the 1990s. Social Policy and Administration, 38(2), 139-155.

Blomqvist, P., \& Rothstein, B. (2000). Välfärdsstatens nya ansikte [The new face of the welfare state]. Stockholm: Agora.

Blomqvist, P., \& Winblad, U. (2013). Sweden: Continued marketization in a universalist system. In E. Pavolini \& A. M. Guillen (Eds.), Public health care systems: Restructuring and retrenchment (pp. 9-25). Basingstoke: Palgrave Macmillan.

Blomqvist, P., \& Winblad, U. (in press). Sweden. In E. Immergut (Ed.), Handbook of health politics in Europe. Oxford: Oxford University Press. 
Bode, I. (2006). Disorganized welfare mixes: Voluntary agencies and the new governance regimes in Western Europe. Journal of European Social Policy, 16(4), 346-359.

Brady, D., \& Bostic, A. (2015). Paradoxes of social policy: Welfare transfers, relative poverty, and redistribution preferences. American Sociological Review, 80(2), 268-298.

Carey, E., Crammond, B., \& de Leeuw, E. (2015). Towards health equity: A framework for the application of proportionate universalism. International Journal for Equity in Health, 14(81). https://doi.org/10.1186/ s12939-015-0207-6

Clayton, R., \& Pontusson, J. (1998). Welfare state retrenchment revisited: Entitlement cuts, public sector restructuring, and inegalitarian trends in advanced capitalist societies. World Politics, 51(1), 67-98.

Earles, K. (2011). Swedish family policy: Continuity and change in the Nordic welfare state model. Social Policy and Administration, 45(2), 180-193.

Edebalk, P. G. (1996). Välfärdsstaten träder fram. Svensk socialförsäkring 1884-1955 [The welfare state emerges. Swedish social insurance 1884-1955]. Lund: Arkiv Förlag.

Esping-Andersen, G. (1990). The three worlds of welfare capitalism. Cambridge: Polity Press.

Gilbert, N. (2002). Transformation of the welfare state. The silent surrender of public responsibility. Oxford: Oxford University Press.

Grees, N. (2015). Stratification in changing Swedish sickness insurance. European Journal of Social Security, 17(4), 453-480.

Hanspers, K., \& Mörk, E. (2011). Förskola. In Laura Hartman (Ed.), Konkurrensen konsekvenser. Stockholm: SNS Förlag.

Hiilamo, H. (2004). Changing family policy in Sweden and Finland during the 1990s. Social Policy and Administration, 38(1), 21-24.

Hinrichs, K. (2004). Active citizens and retirement planning: Enlarging freedom of choice in the course of pension reforms in the Nordic countries and Germany (Working Paper). Bremen: Centre for Social Policy Research, University of Bremen.

Hort, S. (2014). Social policy, welfare state and civil society in Sweden. Volume I: History, policies and institutions 1884-1988. Lund: Arkiv Förlag.

Hsiao, W. (2007). Why is a systemic view of health financing necessary? Health Affairs, 26(4), 950-961.

Immergut, E. (1992). Health politics: Interests and institutions in Western Europe. Cambridge: Cambridge University Press.

Isaksson, D., Blomqvist, P., \& Winblad, U. (2016). Free establishment of primary health care providers: Effects on geographical equity. BMC Health Services Research, 16(28). https://doi.org/10.1186/s12913016-1259-z

Kamerman, S., \& Kahn, A. (2014). Privatization and the welfare state. Princeton, NJ: Princeton University
Press.

Kildal, N., \& Kuhnle, S. (2005). The Nordic model and the idea of universalism. In N. Kildal \& S. Kuhnle (Eds.), Normative foundations of the welfare state: The Nordic experience (pp. 13-33).New York, NY: Routledge.

Klenk, T., \& Pavolini, E. (2015). Restructuring welfare governance: Marketization, managerialism and welfare state professionalism. London: Edward Elgar Publishing.

Korpi, W., \& Palme, J. (1998). The paradox of redistribution and strategies of equality: Welfare state institutions, inequality, and poverty in the Western countries. American Sociological Review, 63(5), 661-687.

Kullberg, L., Blomqvist, P., \& Winblad, U. (2019). Health insurance for the healthy? Voluntary insurance in Sweden. Health Policy, 123(8), 737-746.

le Grand, J., \& Bartlett, W. (1993). Quasi-markets and social policy. London: Macmillan Press.

Lindbom, A. (2001). Dismantling the social democratic model? Has the Swedish welfare state lost its defining characteristics? Scandinavian Political Studies, 24(3), 171-193.

Lindbom, A. (2016). Political partisanship and policy feedback: The Swedish welfare state after eight years of center-right government. In J. Pierre (Ed.), The Oxford handbook of Swedish politics (pp. 37-54). Oxford: Oxford University Press.

Morgan, K. (2012). Promoting social investment through work-family policies: Which nations do it and why? In N. Morel, B. Palier, \& J. Palme (Eds.), Towards a social investment welfare state? Ideas, policies and challenges (pp. 153-180). Bristol: Policy Press.

OECD. (2006). Starting strong II. Early childhood education and care. Paris: OECD Publishing.

OECD, \& European Observatory on Health Systems and Policies. (2019). State of health in the EU. Sweden: Country health profile 2019. Luxembourg: Publications Office of the European Union.

Palme, J. (2003). Pension reform in Sweden and the changing boundaries between public and private. In G. L. Clarke \& N. Whitehead (Eds.), Pension security in the 21st century (pp. 144-167). Oxford: Oxford University Press.

Palme, J. (2005). Features of the Swedish pension reform. The Japanese Journal of Social Security Policy, 4(1), 42-53.

Palme, J., Ferrarini, T., Sjöberg, O., \& Nelson, K. (2012). Sveriges socialförsäkringar i ett jämförande perspektiv [Swedish social insurance in comparative perspective] (Report S 2010:4). Stockholm: The Parliamentary Social Insurance Commission.

Palme, M. (2017). Vem har privat sjukförsäkring i Sverige? [Who has private sickness insurance?]. Stockholm: Department of Economics, Stockholm University.

Palmer, E. (2002). Swedish pension reform: How did it evolve and what does it mean for the future? In M. 
Feldstein \& H. Siebert (Eds.), Social security pensions reforms in Europe (pp. 171-210). Chicago, IL: University of Chicago Press.

Rothstein, B. (1998). Just institutions matter: The moral and political logic of the universal welfare state. Cambridge: Cambridge University Press.

Sheridan, S., Williams, P., Sandberg, A., \& Vurinen, T. (2011). Preschool teaching in Sweden: A profession in change. Educational Research, 53(4), 415-437.

Skocpol, T. (1991). Politically viable policies to combat poverty in the United States. In C. Jencks \& P. E. Peterson (Eds.). The urban underclass (pp. 411-436). Washington, DC: Brookings Institute.

Streeck, W., \& Thelen, K. (2005). Beyond continuity: Institutional change in advanced political economies. Oxford: Oxford University Press.

Svallfors, S. (2016). Who loves the Swedish welfare state? Attitude trends 1980-2010. In J. Pierre (Ed.), The Oxford handbook of Swedish politics (pp. 22-36). Oxford: Oxford University Press.

Swedish Association of Local Authorities and Regions. (2015). Svensk sjukvård i internationell jämförelse
[Swedish health care in comparative perspective]. Stockholm: Sweden's Municipalities and County Councils. Retrieved from https://webbutik.skl.se/ bilder/artiklar/pdf/7585-075-7.pdf

Swedish National Agency of Education. (2018). Barn och personal i förskolan hösten 2017. Enheten för förskole-och grundskolestatistik [Children and staff in the preschool in the fall of 2017] (Dnr.2017:670). Retrieved from https://www.skolverket.se/ publikationer?id=3949

Szebehely, M., \& Meagher, G. (2018). Nordic elder care: Weak universalism becoming weaker? Journal of European Social Policy, 28(3), 294-308.

Thompson, S., \& Hoggett, P. (1996). Universalism, selectivism and particularism: Towards a postmodern social policy. Critical Social Policy, 16, 21-42.

Titmuss, R. M. (1955). Pension systems and population change. The Political Quarterly, 26(2), 152-166.

Titmuss, R. M. (1976). Universal and selective social services. In R. M. Titmuss (Ed.), Commitment to welfare (pp. 113-123). London: George Allen and Unwin.

\section{About the Authors}

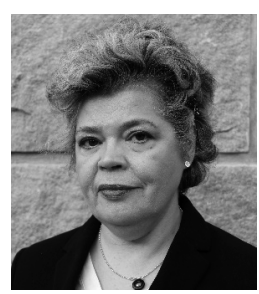

Paula Blomqvist is Associate Professor of political science at the Department of Government, Uppsala University, Sweden, since 2007. Her PhD was earned in 2002 from Columbia University, USA. Her research on the Swedish welfare state, marketization and public governance has been published in a range of scholarly journals and books.

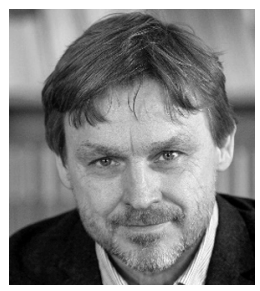

Joakim Palme is Professor of Political Science at the Department of Government, Uppsala University, since 2009. Palme holds a PhD in sociology from 1990, Stockholm University, where he was employed at the Swedish Institute for Social Research. He chaired the Swedish "Welfare Commission" from 1999 to 2001 . From 2002 to 2011 he was the Director of the Institute for Futures Studies in Stockholm. He has published extensively on the welfare state as a strategy of equality and the politics of the welfare state. 